\title{
PENCEGAHAN DEMAM BERDARAH DENGUE (DBD) DI PONDOK PESANTREN AINUL YAKIN KOTA JAMBI
}

\author{
Rahmah $^{1)}$, Nurfitriani ${ }^{2)}$ \\ ${ }^{1}$ Program Studi Profesi Ners, STIKes Baiturrahim Jambi \\ 2 Program Studi D III Keperawatan, STIKes Baiturrahim Jambi \\ email: nurfitriani1173@yahoo.com
}

\begin{abstract}
Dengue Hemorrhagic Fever or commonly called DHF is a problem that often occurs between seasons, such as in Indonesia, usually the transition from the dry season to the rainy season and vice versa. DHF caused by the dengue virus not only attacks children, but now it can attack all age groups. Until now, the handling of DHF has not been able to be addressed optimally, so there are still many cases of deaths from dengue. The high number of dengue cases every year to the end of death certainly requires special handling so that this problem does not continue and there needs to be cooperation between the government and the active role of the community itself. The aim of health education / education on prevention of dengue in Ainul Islamic Boarding School is sure to be able to provide information on dengue prevention and can apply directly to all residents of Islamic boarding schools in order to detect early so that dengue fever outbreaks can be addressed and watched out as early as possible and can reduce the number pain or death.Efforts that can overcome these problems include $3 M$ (draining, closing, burying), maintaining the cleanliness of the house and the environment, do not hang clothes, and immediately seek treatment from the nearest health service if you find complaints such as continuous fever for more than 3 days.
\end{abstract}

Keyword: Dengue virus; Dengue hemorrhagic fever; prevention

\begin{abstract}
ABSTRAK
Penyakit Demam Berdarah Dengue yang sering terjadi peralihan antar musim, seperti di Indonesia biasanya peralihan dari musim kemarau ke musim hujan ataupun sebaliknya. Penyakit DBD yang disebabkan oleh virus dengue bukan hanya menyerang anak-anak, tetapi sekarang ini dapat menyerang semua golongan umur. Penanganan penyakit DBD sampai saat ini belum dapat diatasi dengan optimal, sehingga masih banyak ditemukan kasus kematian akibat penyakit DBD. Tingginya kasus DBD setiap tahun sampai berujung kematian tentunya memerlukan penanganan khusus agar masalah ini tidak berlanjut dan perlu adanya kerjasama antara pemerintah dan peran aktif dari masyarakat itu sendiri. Tujuan penyuluhan / pendidikan kesehatan tentang pencegahan DBD di Pondok Pesantren Ainul Yakin yakni dapat memberikan informasi pencegahan DBD dan mengaplikasikan langsung kepada seluruh warga pondok pesantren sehingga dapat mendeteksi secara dini kejadian demam berdarah dan menurunkan angka kesakitan maupun kematian akibat demam berdarah. Upaya yang dapat mengatasi masalah tersebut antara lain, dengan $3 \mathrm{M}$ (Menguras, Menutup, Mengubur), menjaga kebersihan rumah dan lingkungan, jangan menggantung pakaian, serta segera berobat kepelayanan kesehatan terdekat jika mendapati keluhan seperti demam terus menerus lebih dari 3 hari.
\end{abstract}

Kata Kunci: Virus Dengue; Demam Derdarah Dengue; Pencegahan.

\section{PENDAHULUAN}

Demam Berdarah Dengue atau biasa disingkat dengan (DBD) masih merupakan masalah kesehatan masyarakat, dimana penyakit ini merupakan penyakit endemis disebagian Indonesia dan Provinsi Jambi termasuk daerah yang rawan dengan kejadian DBD (Rampengan,2009). Penyakit Demam Berdarah adalah penyakit infeksi virus akut yang di sebabkan oleh virus Dengue dan sering menyerang anak-anak. Dewasa ini penyakit 
DBD bukan saja menyerang anak-anak namun dapat menyerang semua golongan umur (Maryani, 2010). Berdasarkan data Dinas Kesehatan Provinsi Jambi tahun 2011 ditemukan sebanyak 777, dan sebanyak 14 orng diantaranya meninggal dunia. Sedangkan pada tahun 2014 terdapat 975 orang menderita DBD (Tribun Jambi, 2014). Terlihat jumlah penderita yang dirawat inap mengalami peningkatan dari tahun ketahun. Meningkatnya kecenderungan kasus DBD dan resiko sebagai daerah perlintasan antar wilayah ( yang juga merupakan daerah endemis ) maka kegiatan yang paling efektif dan efisien adalah dengan mencegah terjadinya penularan (Dina, 2009).

Berbagai upaya penanggulangan telah dilaksanakan terutama Pemberantasan Sarang Nyamuk (PSN) melalui "Gerakan 3M Plus"(Menguras, Menutup dan Mengubur) (Anonim,2010). Upaya-upaya ini belum menampakkan hasil yang seperti diharapkan, salah satu penyebabnya tidak optimalnya upaya tersebut karena belum adanya perubahan perilaku masyarakat dalam upaya PSN (Meutia,2009).

Pemberantasan Sarang Nyamuk ( PSN) bukan saja kewajiban pemerintah, namun juga merupakan tanggung jawab kita bersama, sehingga diperlukan kerja sama yang lebih melibatkan pemberdayaan peran serta masyarakat disamping juga kerjasama lintas sektoral dan pihak swasta. Dengan demikian upaya tersebut harus lebih digalakkan lagi terutama menanamkan kesadaran masyarakat pentingnya menjaga kebersihan individu, keluarga dan lingkungan sekitarnya dengan tidak membuang sampah sembarangan, menggantung pakaian, menutup tempat air minum dan menguras bak mandi minimal seminggu sekali.

Pesantren Ainul Yakin Kelurahan Lebak Bandung merupakan salah satu pondok pesantren tempat bermukimnya anak yatim piatu dan kaum dhuafa yang ada di Provinsi Jambi. Pondok pesantren ini juga menyelenggarakan kegiatan pendidikan mulai dari Taman Kanak-Kanak (TK), Sekolah Dasar (SD) sampai dengan Madrasah tsnawiyah (MTs). Madrasah tsanawiyah ini merupakan pendidikan yang setingkat dengan Sekolah Tinggi Menengah Pertama (SMP). Anak-anak yang mondok di pesantren tersebut ada berkisar \pm 250 orang, terdiri dari anak yatim piatu, dan kaum dhuafa. Jika dilihat dari dalam, kondisi kamar anak-anak panti cukup padat, gelap dan kotor, baju bergelantungan, sampah-sampah berserakan, memasak masih menggunakan kayu bakar, dan kebersihan diri anak -anak masih kurang, lingkungan tempat tinggal jika hujan lebat dapat terjadi banjir. Hal ini jika tidak segera diatasi maka kan berdampak dengan kesehatan anak-anak panti tersebut dan dapat menyebabkan penyakit salah satunya Demam Berdarah.

Dari uraian diatas dapat ditarik permasalahannya adalah kurangnya pengetahuan dan motivasi anak panti asuhan di pondok pesantren Ainul Yakin Kota Jambi dalam pencegahan DBD, juga warga pondok belum merasakan hal tersebut merupakan masalah yang harus segera diatasi karena menyangkut dana.

\section{TARGET DAN LUARAN}

Tabel.1 Target Kegiatan Pengabdian

\begin{tabular}{lcl}
\hline TARGET & SEBELUM & SESUDAH \\
\hline 1.Anak-anak dan & 25-30 orang & 59 orang \\
seluruh & & \\
pengurus panti & & \\
mendapatkan & & \\
informasi yang & \\
tepat tentang & \\
DBD &
\end{tabular}

2. Warga Pondok pesantren dapat berkumpul di tempat dan hari

Jarang Masih belum maksimal $(60 \%)$ yang telah disepakati.

3. Warga pondok Jarang Masih belum dapat maksimal memanfaatkan $(40 \%)$

sarana layanan kesehatan yang tersedia

Identifikasi Banyak pemamfaata kegiatan yang akan waktu luang n waktu dilaksanakan kurang luang di luar $\begin{array}{ll}\text { dimanfaat } & \text { jam belajar } \\ \text { kan } & (80 \%)\end{array}$

Penyuluhan Jarang Dilakukan kesehatan (kader aktif

75\%)

Evaluasi Tidak Menyatakan pendidikan dilakukan paham dan kesehatan meminta penkes yang lainnya terkait 


\section{$80 \%)$}

\section{METODE PELAKSANAAN}

Pengabmas ini dilakukan pada bulan Mei s/d Juni 2019. Solusi yang dirancang dalam kegiatan pengabdian masyarakat ini sesuai dengan tahapan sebagai berikut:

1. Temu ketua Pondok Pesantren, dengan melakukan identifikasi kegiatan dan penjadwalan kegiatan. Metode yang digunakan dengan cara Diskusi di Pondok Pesantren Ainul Yakin

2. Perumusan Solusi, dengan melakukan identifikasi masalah di Pondok Pesantren, menyusun strategi pelaksanaan dan pmbuatan leaflet. Metode yang digunakan dengan melakukan diskusi dan tanya jawab di Pondok Pesantren Ainul Yakin..

3. Pemberian informasi / penyuluhan kesehatan dengan materi Pencegahan Demam Berdarah Dengue (DBD), melalui ceramah, diskusi dan tanya jawab, pemberian leaflet di Masjid pondok pesantrn..

4. Evaluasi dan monitoring dengan melakukan pembinaan dan pengawasan dengan cara review pencegahan demam berdarah dengan melakukan gotong royong setiap hari minggu di Pondok Pesantren Ainul Yakin.

\section{HASIL DAN PEMBAHASAN}

Kegiatan pengabdian masyarakat ini dilaksanakan di bulan Mei s/d Juni 2017 bertujuan memberikan wawasan dan pengetahuan pada anak anak dan pengurus pondok pesantren Ainul Yakin Jambi. Kegiatan ini terlaksana dengan mengadakan temu pengurus pondok dan mengidentifikasi masalah yang ada di pondk terutama masalah kebersihan diri. Dari hasil penyuluhan dan diskusi dengan warga pondok, rata rata anak anak mulai memahami beberapa cara yang dapat dilakukan untuk mencegah penyakit demam berdarah di Pondok Pesantren yaitu slah satunya dengan menjaga kebersihan diri dan lingkungan seperti tidak membuang ampah sembarangan, membersihkan bak mandi seminggu sekali, tidak menggantung pakaian yang telah di gunakan dan menumpuk barang bekas sembarangan agar terhindar dari kejadian dmam berdarah maupun penyakit lainnya. Namun dari hasil identifikasi masih kurangnya penyuluhan yang dilakukan di Pondok Pesantren dan pemanfaatan waktu luang yang belum maksimal serta Poskestren yang beralih fungsi menjadi gudang.

Hal ini perlu mendapatkan perhatian yang serius dan tindak lanjut agar anak anak pondok sehat dapat menjadi penerus bangsa yang kuat fisik dan mentalnya.

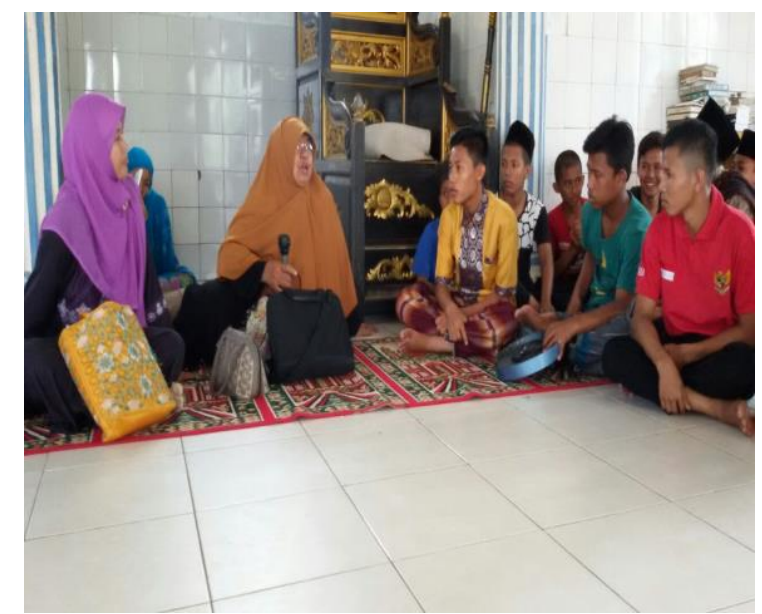

Gambar 1. Pelaksanaan Penyuluhan

\section{KESIMPULAN DAN SARAN}

\section{A. KESIMPULAN}

Dengan adanya pengabdian masyarakat di Pondok Pesantren Ainul Yakin Jambi, pengurus pondok dapat memotivasi dan menggerakkan anak-anak warga pondok pesantren Ainul Yakin Lebak Bandung ikut serta kegiatan penyuluhan kesehatan, juga gotong royong agar tercipta suasana pondok pesantren yang bersih dan asri sehingga terhindar dari penyakit demam berdarah.

Hasil pengabdian masyarakat ini adalah anak-anak warga pondok pesantren dapat memahami dan mengenali penyakit demam berdarah dan upaya pencegahannya, agar mereka terhindar dari penularan penyakit demam berdarah.

\section{B. SARAN}

1. Bagi Puskesmas Simpang Kawat Jambi Agar dapat lebih mengoptimalkan lagi peran puskesmaskhususnya Pustu Lebak Bandung dalam memberikan pendidikan kesehatan khususnya tentang Perilaku hidup Bersih dan Sehat (PHBS) sehingga program yang ada dapat terlaksana dan dapat beroordinasi dengan pihak pondok untuk kesehatan anak anak pondok sehingga dapat meningkatkan 
derajat kesehatan khususnya warga pondok pesantren Ainul Yakin Jambi.

2. Bagi Insitusi STIKBA Jambi

Sebagai bahan bacaan dan kajian bagi ilmu kesehatan serta memotivasi bagi dosen agar dapat menjalankan perannya dalam tri darma perguruan tinggi dan pengabdian masyarakat dan memotivasi mahasiswa ikut terlibat dalam pengabdian tersebut.

\section{UCAPAN TERIMAKASIH}

Termakasih kepada Sekolah Tinggi Ilmu Kesehatan Baiturrahim dan Ketua Pengurus Pondok Pesantren Ainul Yakin Jambi yang telah memberikan dana dan memfasilitasi kegiatan pengabdian kepada masyarakat ini.

\section{DAFTAR PUSTAKA}

Ahmad, 2009. Tingkat Pengetahuan, Sikap dan Praktek Keluarga Tentang Pencegahan DBD. Jakarta : Skripsi. Perpus. Fkik.uinjkt.ac.id./file_digital /Ahmad.pdf. 30-08-2012 jam 10:06 wib.

Anton, 2008. Hubungan Perilaku Tentang Pemberantasan Sarang Nyamuk dan Kebiasaan keluarga dengan Kejadian Demam Berdarah Dengue. Medan: Skripsi.

Eprints.undip.ac.id/16497/1/Anton.pdf. 31-12-2011 jam 09:34 wib.

2010. Program Peningkatan Peran Serta Masyarakat dalam Pemberantasan Sarang Nyamuk Demam Berdarah Dengue (PSN-DBD) di Kabupaten/Kota. Jakarta: Ditjen PPM \& PLP

Dina, 2009. Gambaran Pengetahuan, Sikap dan Tindakan Mengenai DBD pada Keluarga. Medan: Skripsi. Repository. Usu. ac.id. 30-08-2012 jam 10:10 wib.

Data Dinkes Kota Jambi, 2011. Profil Kesehatan Provinsi Jambi

Meutia, 2009. Gambaran Pengetahuan, Sikap dan Tindakan Tentang $3 M$ Pada Keluarga. Medan: Skripsi. Repository. Usu. ac.id. /bitstream/ 123456789 /14262/1/09E02923.pdf. 31-12-2011 jam 09:28 wib.
Mubarak, Wahid. Iqbal dan Chayatin. 2009. Ilmu Kesehatan Masyarakat: Teori dan Aplikasi. Jakarta : Salemba Medika

Murwani, 2008. Perawatan Pasien Penyakit Dalam. Jogjakarta : Mitra Cendikia

Nurfitriani, 2012, Peran Keluarga Dalam Upaya Pencegahan Penyakit DBD di kel. Mayang Mengurai Kec. Kota Baru Jambi. Scientia Journal Stikes Prima. ISSN 2302 - 9862

Pambudi, 2009. Faktor-faktor yang Mempengaruhi Partisipasi Kader Jumantik dalam Pembrantasan DBD. Surakarta:Skripsi.Etd.eprimnts.ums.ac.id. / 01-01-2012 jam 12:39 wib.

Rampengan,2008. Penyakit Infeksi Tropis pada Anak.Jakarta:EGC.

Sudarto,2009, Penyakit Menular di Indonesia. Jakarta:Sagung Seto.

Widia, 2009. Beberapa Faktor yang Berhubungan dengan Kejadian Demam Berdarah Dengue. Surakarta: Skripsi. Etd.eprints.ums.ac.id. 31-12-2011 jam 09:28 wib. 